Mari-Elisa Kuusniemi, Susanna Nykyri, Seliina Päällysaho, Jukka Rantasaari, Eeva Savolainen ja Anne Sunikka

\title{
DATATUKEA RAKENTAMASSA - KATSAUS KOULUTUKSIIN JA PALVELUIHIN
}

Korkeakouluissa on viime vuosina kehitetty ahkerasti datanhallintaan liittyviä koulutuksia ja palveluja. Toiminnalle on leimallista moniammatillisuus, yhteistyö ja jatkuva kehitys. Palvelutarjonnassa on paljon yhtäläisyyksiä, mutta myös paikallisia ratkaisuja.

$\mathrm{K}$ ansainväliset, kansalliset ja korkeakoulujen organisaatiokohtaiset linjaukset korostavat hyvän aineistonhallinnan tärkeyttä. Datanhallintaan liittyvät koulutukset ja palvelut ovatkin yhä keskeisempi osa korkeakoulujen tukitoimintojen palvelutarjontaa. Datapalvelujen historia korkeakouluissa on vielä suhteellisen lyhyt, ja palveluja kehitetään jatkuvasti yhteistyössä sekä kansainvälisesti, kansallisesti että paikallisesti.

Tässä artikkelissa hahmottelemme datakoulutusten ja -palvelujen nykytilannetta sekä kansallisella että paikallisella tasolla. Kansallisessa avoimen tieteen koordinaatiossa tehdyn työn kuvauksesta edetään Helsingin yliopiston yhteydessä toimivan Tuulitoimiston esittelyyn, jonka jälkeen siirrytään tarkastelemaan tämänhetkistä tilannetta Aalto-yliopistossa, Helsingin yliopistossa, Tampereen yliopistossa, Turun yliopistossa ja Seinäjoen ammattikorkeakoulussa.

\section{Kansallinen konteksti}

\subsection{Datakoulutukset ja -palvelut avoimen tieteen koordinaatiossa}

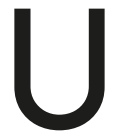

nescon tuore avoimen tieteen linjausluonnos (Unesco 2020) korostaa avoimen tieteen laaja-alaista osaamisen kasvattamista. Kyky datanhallintaan on linkitettävä tutkijaroolin eri vaiheisiin ja luettava osaksi tutkijavalmiuksia. Jotta avoin tiede etenee, tarvitaan ammatillista erikoistunutta tukihenkilöstöä, joka kouluttaa tutkijoita, kuratoi dataa ja varmistaa, että data on FAIR (löydettävissä, saavutettavissa, yhteentoimivaa ja uudelleenkäytettävissä). Kansainvälisellä tasolla asiaa edistetään monissa eri yhteyksissä, kuten EOsc:n (European Science Cloud) Skills and Training -työryhmässä ja monissa RDA:n (Research Data Alliancen) työ- ja intressiryhmissä.

Kansallinen tutkimusaineistojen avoimuutta linjaava työryhmä on samoilla linjoilla. Juuri kommentoitavana olleessa ensimmäisessä linjausluonnoksessa 
painotettiin datanhallinnan osaamista, organisaatioiden valmiuksia tarjota ja kehittää tukipalveluita sekä tutkijoiden ja datanhallinnan asiantuntijoiden osaamisen kehittämistä.

Suomessa avoimen tieteen edistämistä koordinoi kansallisella tasolla Tieteellisten seurain valtuuskunta (TSv). Avoimen tieteen koordinaation tutkimusaineistojen avoimuuden asiantuntijaryhmän Datakoulutukset-työryhmä kehittää datanhallinnan koulutuksia ja tukee organisaatioita koulutuksiin liittyvässä kehitystyössä. Ensimmäisen toimintavuoden aikana työryhmä järjesti kaksi koulutusta kouluttajille: ensimmäisen aiheena oli anonymisointi ja toisessa esiteltiin erilaisia datatukimalleja. Lisäksi ryhmä kartoitti aktiivisesti eri toimijoiden (tutkimus- ja tukiorganisaatiot) tarjoamia koulutuksia ja jakoi käytänteitään.

Toisena toimintavuonna huomio on edelleen koulutustiedon keräämisessä sekä koulutusten suunnittelussa opintojen eri vaiheessa oleville opiskelijoille (esim. kandi- tai maisteriopiskelijat, AMK-opiskelijat, tohtoriopiskelijat) ja tutkijoille. Työryhmässä kerätään lisäksi tietoa siitä, kuka järjestää datakoulutuksia ja tarjoaa datanhallinnan tukea ja kuinka paljon resursseja tämä vaatii eri tutkimusorganisaatioissa.

Datakoulutukset-ryhmän ohella datapalvelujen kehitystä edistävät kansallisella tasolla kaksi vuonna 2020 perustettua uutta työryhmää, Palvelut avoimen FAIR -toimintakulttuurin edistäjinä ja Tutkijan datapalvelujen markkinointi.

\subsection{Tuulitoimisto edistää datanhallinnan suunnittelua}

Opetus- ja kulttuuriministeriön rahoittaman, Helsingin yliopiston kirjastossa toimivan Tuulitoimiston tehtävänä on edistää datanhallinnan suunnittelua Suomessa. Tuulitoimiston toiminta alkoi projektina vuonna 20 I 5 ja siirtyi jatkuvaksi toiminnaksi vuonna 2019. Tuulitoimiston toimintaa ohjaa ohjausryhmä, jonka puheenjohtajana toimii Avoimen tieteen kehittämispäällikkö Henriikka Mustajoki (Tsv). Muut ohjaus-

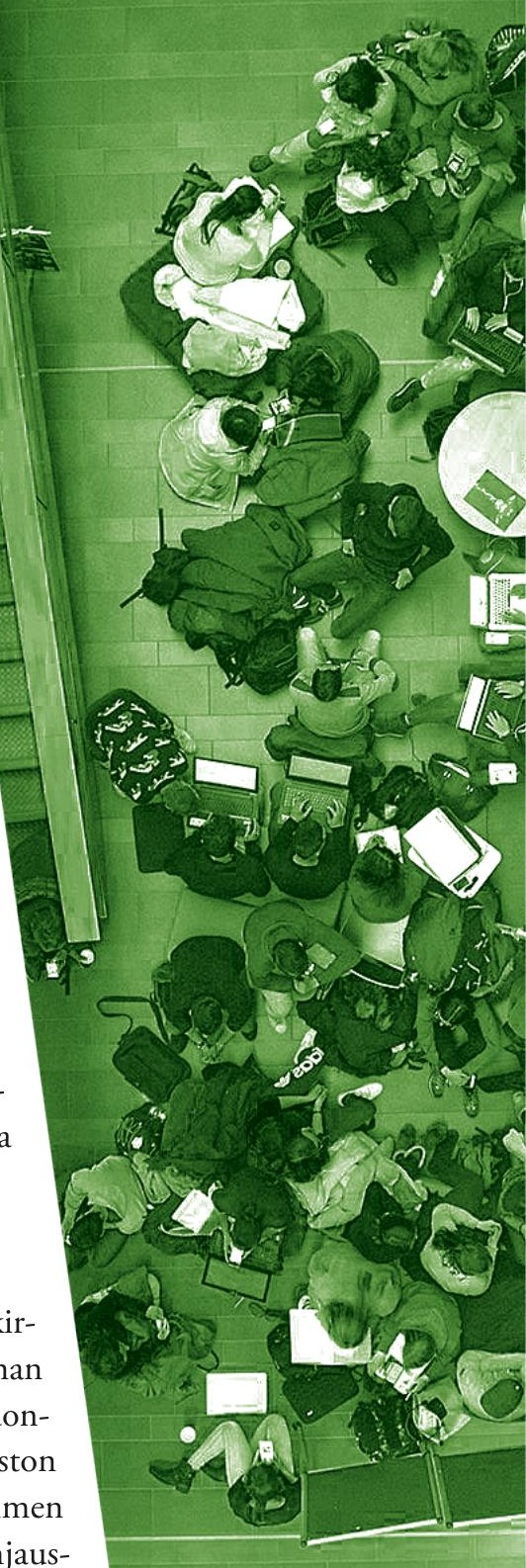

kuva: Sofia Niemelä SeAMK-kuvapankki 
ryhmän jäsenet ovat korkeakoulujen, tutkimuslaitosten ja Tsv:n edustajia.

Tuulin toiminta perustuu pitkälti vapaaehtoisvoimin toimiviin asiantuntijatyöryhmiin. Kansallisia datanhallinnan vaatimuksia ja ohjeita ylläpidetään vuosittain koottavassa työryhmässä, joka tarkistaa ja päivittää alun perin vuonna 2016 luotua suunnitelmapohjaa ja ohjeita. Kansallista suunnitelmapohjaa käyttävät lähes kaikki suomalaiset tutkimusrahoittajat sekä suuri osa korkeakouluista ja muista tutkimusorganisaatioista.

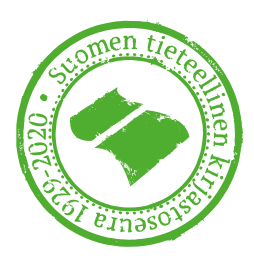

Tuulitoimisto pitää yllä ja kehittää DMPTuulia eli verkkotyökalua, josta löytyvät kansainvälisten tutkimusrahoittajien suunnitelmapohjat sekä yleiset kansalliset että tutkimusorganisaatioiden omat ohjeet datanhallintasuunnitelmien tekemiseen. Työkalun kehittämiseksi käyttäjiltä kerätään palautetta säännöllisesti, vuorovuosin tukipalveluiden edustajilta ja kaikilta käyttäjiltä.

Datanhallinnan suunnittelun osaamisen kasvattaminen on Tuulitoimiston tärkein tehtävä. Tätä varten on perustettu Tuuliverkosto, joka järjestää (verkko)keskustelutilaisuuksia, työpajoja ja koulutuksia. Verkostolla on myös oma sähköpostilista. Tuuliverkostolaiset osallistuvat aktiivisesti tapahtumien järjestämiseen. Työpajat ovat keskustelevia ja tuotteliaita. Verkoston toimintaan osallistuminen onkin hyvä keino ammatillisen osaamisen kasvattamiseen. Syksyn 2020 uutuutena on
Datanhallinnan suunnittelu -koulutus kouluttajille, joka järjestettiin kolmen verkkokoulutuksen sarjana loka-marraskuussa.

Tuulitoimisto tekee yhteistyötä suomalaisten tutkimusrahoittajien kanssa ja osallistuu kansainväliseen keskusteluun esim. Science Europen kautta. Nousevana trendinä on datanhallintasuunnitelmien tärkeyden korostaminen FAIR datan tuottamisen edellytyksenä. Lisäksi datanhallintasuunnitelmista halutaan kehittää koneluettavia ja dynaamisia. Tuulitoimiston suurin haaste tulee olemaan näiden toiveiden sovittaminen yhteen tutkijoiden heterogeenisen datanhallinnan suunnittelutarpeiden kanssa.

\section{Organisaatioiden datakoulutukset ja palvelut}

\subsection{Moniammatillista yhteistyötä}

Datapalvelut ovat useimmissa organisaatioissa vielä lapsenkengissä, näin myös esimerkkitapauksissamme: palvelujen syntyvuosi hahmottuu useimmiten vuoteen 20 I 5 tai sen jälkeiseen aikaan. Projekteilla ja hankkeilla on usein ollut tärkeä rooli toimintojen käynnistämisessä, ja strategiasta ja linjauksista on saatu tarvittavaa selkänojaa. Keskeisiä toimenpiteitä ovat olleet asiantuntijaverkoston muodostaminen, yhteistyöstä sopiminen sekä palvelu- ja koulutustarjonnan suunnittelu 
(ks. esim. Nykyri \& Näppilä 2019 ja Violos, J. et al. 2020).

Kirjastoilla on vahva rooli palvelujen koordinoinnissa ja datanhallinnan koulutuksessa. Aalto-yliopiston malli poikkeaa muista yliopistoita, sillä datatukea tarjoaa tutkimuspalvelut, jonne osa kirjaston henkilökuntaa siirtyi vuoden 2018 organisaatiomuutoksen jälkeen. Tavallisimmin palveluja tuotetaan moniammatillisessa verkostossa, johon kuuluu asiantuntijoita kirjaston ja tutkimuspalvelujen lisäksi muun muas-

\section{Tavallisimmin} palveluja tuotetaan moniammatillisessa verkostossa. jotaan myös tukipalveluhenkilöstölle. Koulutuksia myös räätälöidään tieteenalakohtaisesti. SeAmkissa koulutuksen kohderyhmiä ovat henkilöstön lisäksi perustutkinto-opiskelijat. Perustutkinto-opiskelijoiden datanhallintakoulutusta pyritään kehittämään myös yliopistoissa. Esimerkiksi Tampereella data-asioita käsitellään perusopiskelijoiden IL-opetuksessa ja graduryhmätyöskentelyyn osallistumalla.

Tampereella on havaittu eroja eri kohderyhmien osallistumisaktiivisuudessa. sa tietohallinnosta ja lakipalveluista. Tampereen yliopistossa asiantuntijaverkostoon kuuluvat myös esimerkiksi asiakirjahallinto ja tutkimusaineistojen hallintaan erikoistunut Tietoarkisto. Korkeakoulun eri yksikköjen lisäksi yhteistyötä tehdään kansallisissa ja kansainvälisissä verkostoissa.

Myös tutkijat osallistuvat datapalvelujen tuottamiseen. Esimerkiksi Aalto-yliopistossa toimii tutkijoista koostuva data-agenttien verkosto, joka toimii datanhallinnan lähitukena kouluissa ja laitoksilla. Turussa tutkijat ovat osallistuneet Basics of Research Data Management (BRDM) -koulutuksen suunnitteluun ja toteutukseen.

\subsection{Datakoulutukset} Kohderyhmät

Yliopistoissa koulutusten keskeisiä kohderyhmiä ovat tohtorikoulutettavat, opinnäytetöiden ohjaajat ja postdoc-tutkijat, mutta koulutusta tar-
Vaikka datatuki on tarkoitettu kaikille korkeakouluyhteisön jäsenille, datanhallinnan tukea on käytetty yliopistossa merkittävästi aktiivisemmin kuin TAMKissa. Esimerkiksi lisenssiseminaarin osallistujista valtaosa oli yliopistolta, vaikka sisältö oli relevantti myös ammattikorkeakoululle. Osallistujaprofiilien tarkastelusta on hyötyä jatkokehittämiselle ja markkinoinnille.

\section{Koulutusaiheet}

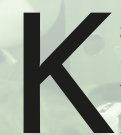
aikki organisaatiot tarjoavat koulutusta datanhallinnan perusteista, datanhallintasuunnitelmista ja tietosuojasta. Osalla organisaatioista on erillisiä koulutuksia datan dokumentoinnista, tallennusratkaisuista sekä aineiston avaamisesta ja uudelleenkäytöstä, toisissa näitä teemoja on nivottu mukaan laajempiin kokonaisuuksiin.

Datanhallinnan perusteiden koulu- 
tuksen organisoinnissa on eroja. Aalto-yliopistossa kokonaisuuteen kuuluu tunnin mittainen johdantoluento, jonka lisäksi tarjotaan I-I, 5 tunnin mittaisia luentoja henkilödatan käsittelystä tallennusratkaisuihin ja datasettien julkaisemiseen. Lisäksi data-agentit tarjoavat tieteenalakohtaisia työpajoja. Helsingissä tarjotaan kahden tunnin mittaista Research Data Management Basics -luentoa, ja ensi keväästä lähtien syventävää RDM Advanced -kurssia, jonka kesto on $4-5 \times 2$ tuntia, ja josta on tarkoitus saada jatkossa myös opintopisteitä.

Tampereella tutkimusaineistojen hallinta on yksi neljästä teemakokonaisuudesta kolmen opintopisteen Managing Research Information -kurssia, jonka muita teemoja ovat tieteellisen tiedon hankinta, näkyvyys ja vaikuttavuus sekä OA-julkaiseminen. Kirjaston vastuulla on myös yhden opintopisteen laajuinen Tutkimuksen aineistonhallinta - kysely- ja haastatteluaineisto -kurssi, ja aineistonkeruun ja hallinnan periaatteita koskeva luento Tutkimusetiikka-kurssilla. Perustutkinto-opiskelijoita tutustutetaan datan saloihin IL-opetuksen ja graduseminaarien yhteydessä ja opinäytetyönohjaajien koulutuksen myötä.

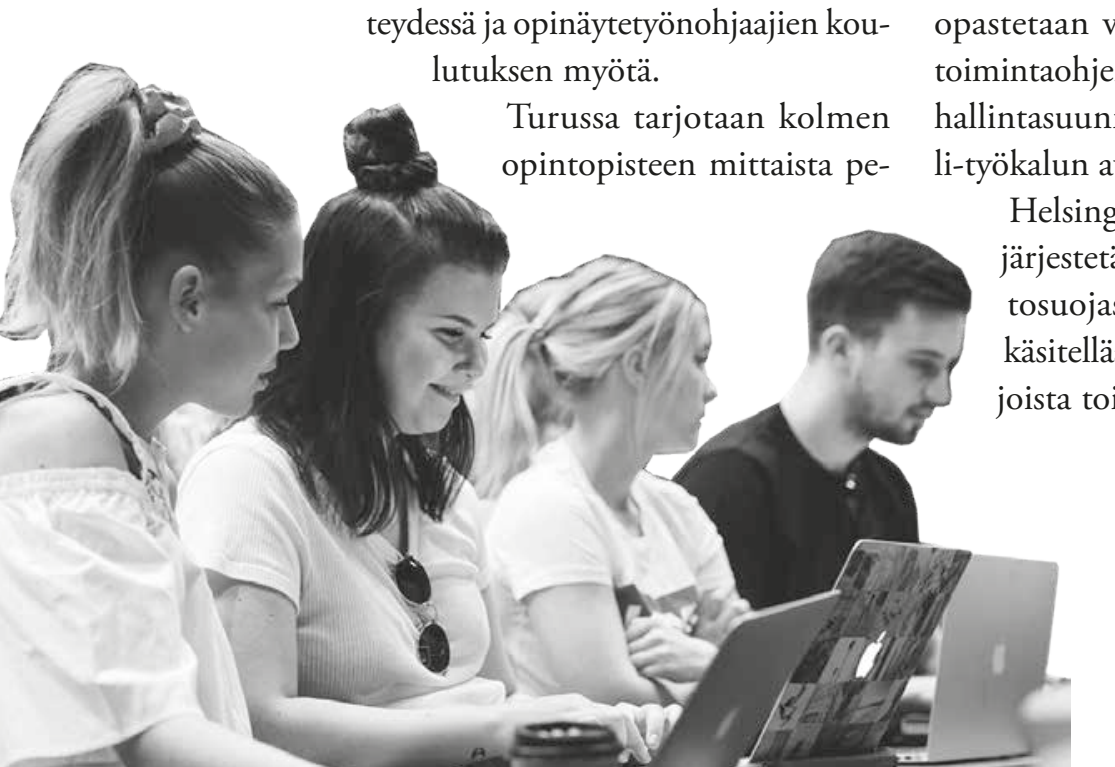

«kuva: Tuukka Kiviranta SeAMK-kuvapankki ruskurssia, joka on eriytetty neljäksi eri tieteenala/datatyyppikohtaiseksi opintolinjaksi. Koulutuksen ja myös muiden palvelujen suunnittelun perustana ovat Turussa toimineet tohtorikoulutettavien ja heidän ohjaajiensa haastattelut, joiden pohjalta saatiin tietoa muun muassa tutkijoiden datanhallinnan käytännöistä ja osaamistarpeista (Rantasaari, 2020a; Rantasaari \& Kokkinen, 2019).

Helsingin ja Turun yliopistoissa sekä Aalto-yliopistossa datanhallintasuunnitelmakoulutusten formaattina on kahden tunnin mittainen työpaja. Aallossa työpaja sisälsi alustuksen lisäksi DMPTuulin esittelyn ja Suomen Akatemian suunnitelmapohjan läpikäynnin vastausesimerkkien avulla. HY:ssä ja Turussa oli alustuksen lisäksi mahdollista työstää omaa datanhallintasuunnitelmaa. Tampereella datanhallintasuunnitelman tekemistä käsitellään Aineistonhallintaa ja tietosuojaa -koulutuksessa, jonka lisäksi erityisesti Suomen Akatemian haun yhteydessä järjestetään työpajoja. Seinäjoen ammattikorkeakoulu tarjoaa seitsemästä lyhyestä videosta koostuvaa DMPTuuli-verkkotyöpajaa, jossa opastetaan vaihe vaiheelta SeAmkin toimintaohjeiden mukaisen aineistonhallintasuunnitelman teko DMPTuuli-työkalun avulla.

Helsingin ja Turun yliopistossa järjestetään erillisiä luentoja tietosuojasta. Aallossa tietosuojaa käsitellään kahdella eri luennolla, oista toisen aiheena on henkilö- 


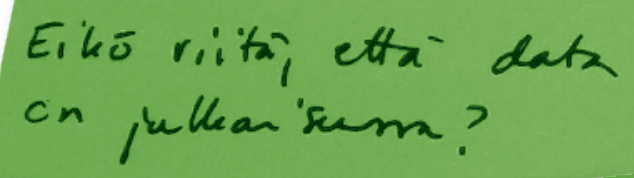

datan käsittely yleisesti

ja toisen henkilödataan

liittyvät tallennusrat-

kaisut. Tampereella

tietosuojaa käsitellään

yhdistettynä tietotur-

vaan ja datanhallinnan

koulutuksissa on vakioi-

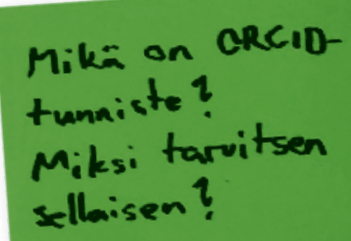

tuna Aineistonhallintaa ja tietosuojaa -koulutus, josta tietosuojan osuus on noin puoli tuntia. SeAmkissa järjestetään tietosuojaan, tutkimusetiikkaan ja aineistonhallintaan liittyvää koulutusta, jota tarjotaan opiskelijoille siinä vaiheessa kun he aloittavat opinnäytetöidensä tekoa.

\section{Erilaisia lähestymistapoja}

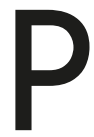
erinteisten koulutusten lisäksi on testattu myös muita lähestymistapoja. Tampereella on kokeiltu esimerkiksi haastattelumuodossa toteutettuja koulutuksia. Karnevalistisia tapahtumia on testattu ainakin Tampereella ja Aallossa. Monissa organisaatioissa on järjestetty lisäksi sekä lyhyitä tietoiskuja että laajempia seminaareja tilanteen mukaan. Lähiopetuksen lisäksi tarjotaan verkkoluentoja ja verkkokursseja.

Koulutuksia järjestetään sekä omina kokonaisuuksinaan että integroituna laajempiin kokonaisuuksiin. Tampereella väitöskirjatutkijoille suunnattu Tutkimusetiikka-kurssi sisältää luennon aineistonhallinnasta ja etiikasta, ja Aalto-yliopistossa aloittaville väitöskirjatutkijoille järjestetään kolmesti vuodessa tietoisku avoimesta tieteestä,

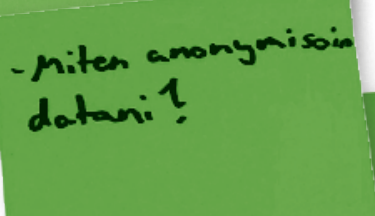

datanhallinnasta ja tutkimusetiikasta. Seinäjoella datanhallinnan koulutusta on integroitu osaksi henkilöstölle suunnattuja TKI-koulutuksia ja SeAмк-akatemian koulutuksia. Opiskelijoille tarjotaan yhden opintopisteen laajuista Avoimen tutkimusja kehittämistoiminnan perusteet -CampusOnline-opintojaksoa, joka on osa viiden opintopisteen laajuista kokonaisuutta.

\subsection{Muut datapalvelut}

Kaikissa organisaatioissa on käytössä yksi tai useampi palveluosoite, jonka kautta datanhallinnan asiantuntijat tavoittaa. Helsingin yliopistossa tiedusteluja tulee kuukaudessa noin 50, Tampereella yli 20, ja Aallossa alle ro. SeAmkissa palveluosoitteeseen on koko sen historian aikana tullut vain muutamia tiedusteluja. Tiedustelujen määrään vaikuttavat luonnollisesti monet seikat kuten organisaation koko, palveluosoitteen tunnettuus ja toimintatavat. Asiantuntijoita lähestytään usein myös henkilökohtaisesti palveluosoitteen sijaan.
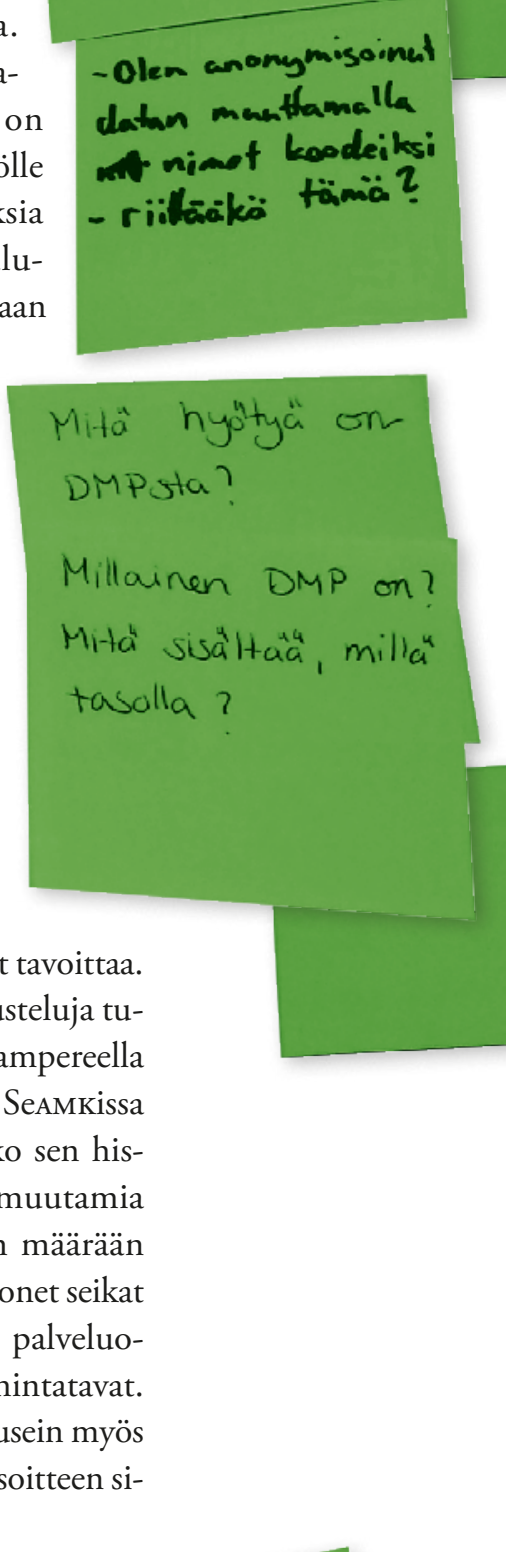

hyótyă on a?

en DMP on? sisätaca, milla a ? 
Helsingin yliopistossa tiedustelujen tavallisimpia aihepiirejä ovat tallennusratkaisut ja sensitiivisen datan käsittely. Aallon palveluosoitteeseen on toistaiseksi tullut eniten tiedusteluja Suomen Akatemian vuoden 2019 hakuun liittyvistä datanhallintasuunnitelmista. Tutkimusrahoitushakujen datanhallintasuunnitelmat ja erityisesti niihin liittyvät tietosuojakysymykset ovat merkittävä aihealue myös Tampereen yliopiston palveluosoitteeseen tulleissa tiedusteluissa. Tallennusratkaisuja koskevat tiedustelut lähetetään Tampereella toistaiseksi ensisijaisesti tietohallinnon palveluosoitteisiin, mutta datapalvelun tunnettuuden lisääntyessä keskitetyn palveluosoitteen käyttö myös näissä aiheissa tulee todennäköisesti kasvamaan.

Turussa on käytössä kaksi aineistonhallintaan liittyvää palveluosoitetta. Kirjaston koordinoima openutu@utu.fi keskittyy aineistonhallinnan lisäksi esimerkiksi avointa julkaisemista, avoimen julkaisemisen maksuja ja kustantajapolitiikkoja koskeviin kysymyksiin, ja sinne tulee noin I 50 tiedustelua vuodessa. Toinen osoite, tutkimuksen IT:n koordinoima data@utu.fi, vastaa pääasiassa datan tutkimuksen aikaista tallennusta ja REDCap-datankeruuohjelmaa koskeviin kysymyksiin. Kahden toimintavuotensa aikana palveluosoitteeseen on lähetetty yhteensä noin Ioo kysymystä.

Ammattikorkeakoulujen avoin TKI-toiminta, oppiminen ja innovaatioekosysteemi -hankkeessa on kehitteillä kiinnostava toimintamalli, yhteinen helpdesk-verkosto. Verkoston tavoitteena on koota yhteen eri ammattikorkeakoulujen asiantuntijat, jakaa hyviä käytänteitä ja osaamista sekä antaa vertaistukea isojen ja pienten ongelmien kanssa painiskeleville asiantuntijoille.

\section{Päivystystä, verkko-oppaita, datanhallintasuunnitelmien kommentointipalvelua}

oulutusten lisäksi organisaati-
oissa tarjotaan myös päivystys-
tyyppistä neuvontaa. SeAmkissa järjestetään noin kerran kuussa ns. Repo-tunteja, joiden aikana asiakkaat saavat henkilökohtaista neuvontaa aineistonhallintaan liittyvissä kysymyksissä. Aalto-yliopiston data-agentit ovat järjestäneet säännöllisesti konsultaatioita omilla kouluillaan ja laitoksillaan, ja syksyllä 2020 kokeillaan viikoittaisia datanhallinnan Zoom-päivystyksiä.

Kaikki organisaatiot tarjoavat datanhallintaan liittyvää tukea ja oppaita verkkosivuillaan. Sisällöissä on paljon samaa, mutta organisointi ja esitystapa vaihtelee. Punaisena lankana toimii tutkimuksen tai SeAmkin osalta TKI-hankkeen elinkaari. Ohjeistusta tarjotaan tutkimusdatan hallinnan eri vaiheisiin aina suunnittelusta aineistojen avaamiseen. SeAmkin ja Aalto-yliopiston oppaissa otetaan kantaa myös tulosten kaupalliseen hyödyntämiseen, Turun yliopiston opas sisältää puolestaan yleisten datanhallintaohjeiden lisäksi myös tiedekuntakohtaisia ohjeita. SeAmkin opinnäytetyöohjeissa on ai- 
neistonhallinnasta oma osionsa.

Datanhallintasuunnitelmien kommentointipalvelua tarjotaan kaikissa tarkasteltavana olevissa organisaatioissa. Helsingin yliopisto käynnisti datanhallintasuunnitelmien kommentointipalvelun vuonna 2015 EU:n Horizon-rahoitushakuun liittyvistä datanhallintasuunnitelmista. Vuonna 20 I 6 palvelu laajennettiin koskemaan Suomen Akatemian hakuja, ja nykyisin kirjaston datatuesta voi pyytää kommentteja kaikkiin datanhallintasuunnitelmiin. Palvelua tuottaa kirjaston datatiimi, joka konsultoi tarvittaessa datatukiverkostoa, johon kuuluu asiantuntijoita kirjastosta, tietotekniikkakeskuksesta ja tutkimuspalveluista.

Tarjolla on lisäksi esimerkiksi kuvailutietoihin, eettiseen ennakkoarviointiin ja ohjelmistokehitykseen liittyviä palveluja. Aalto-yliopistossa kirjataan data-arkistoihin tallennettujen datasettien tietoja pyynnöstä tutkimustietojärjestelmään, Turussa suunnitellaan parhaillaan palvelua kuvailevan metatiedon täydennyksen tueksi. Ainakin Aallossa, TAUssa ja HY:1lä datakysymyksiä arvioidaan eettisen ennakkoarvioinnin yhteydessä. Turussa tutkimuksen IT tarjoaa projekteille maksullista palvelua tutkimusprojektien tarvitsemaan ohjelmistokehitykseen.

\section{Innolla eteenpäin: uusia} palveluja ja kehityskohteita Datanhallintaan liittyviä palveluja pyritään kehittämään jatkuvasti yhteistyössä. Vuosien varrella ammattikorkeakoulujen ja yliopistojen yhteistyönä on kehitetty muun muassa datanhallinnan koulutuksia, sopimusmalleja ja tietosuojaan liittyviä lomakkeita. Myös käyttäjät ovat kehitystyössä mukana.

Aalto-yliopistossa tulevaisuuden tavoitteena on integroida datanhallinta tiiviimmin yliopiston prosesseihin. Vuoden 202 I aikana tarkastellaan IT-yksikön kanssa tietokantaratkaisuja, jotta datasta voidaan kerätä joustavasti tietoja tutkimuksen eri vaiheissa. Vuoden 202 I tavoitteisiin kuuluu myös CsC:n kanssa tehtävä yhteistyö, jossa tietoja tutkimusorganisaatioiden dataseteistä siirretään kansalliseen tutkimustietovarantoon ja portaaliin.

Helsingin yliopistossa kiireisimpiä kehitysprojekteja on yliopiston tutkimuksessa tuotettujen data-aineistojen metatietojen kerääminen.

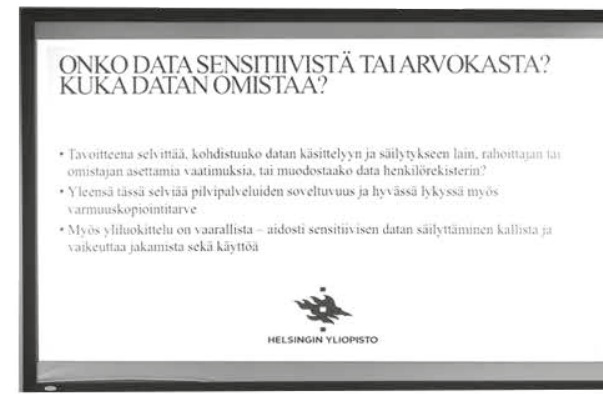

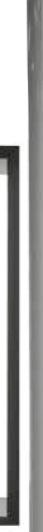
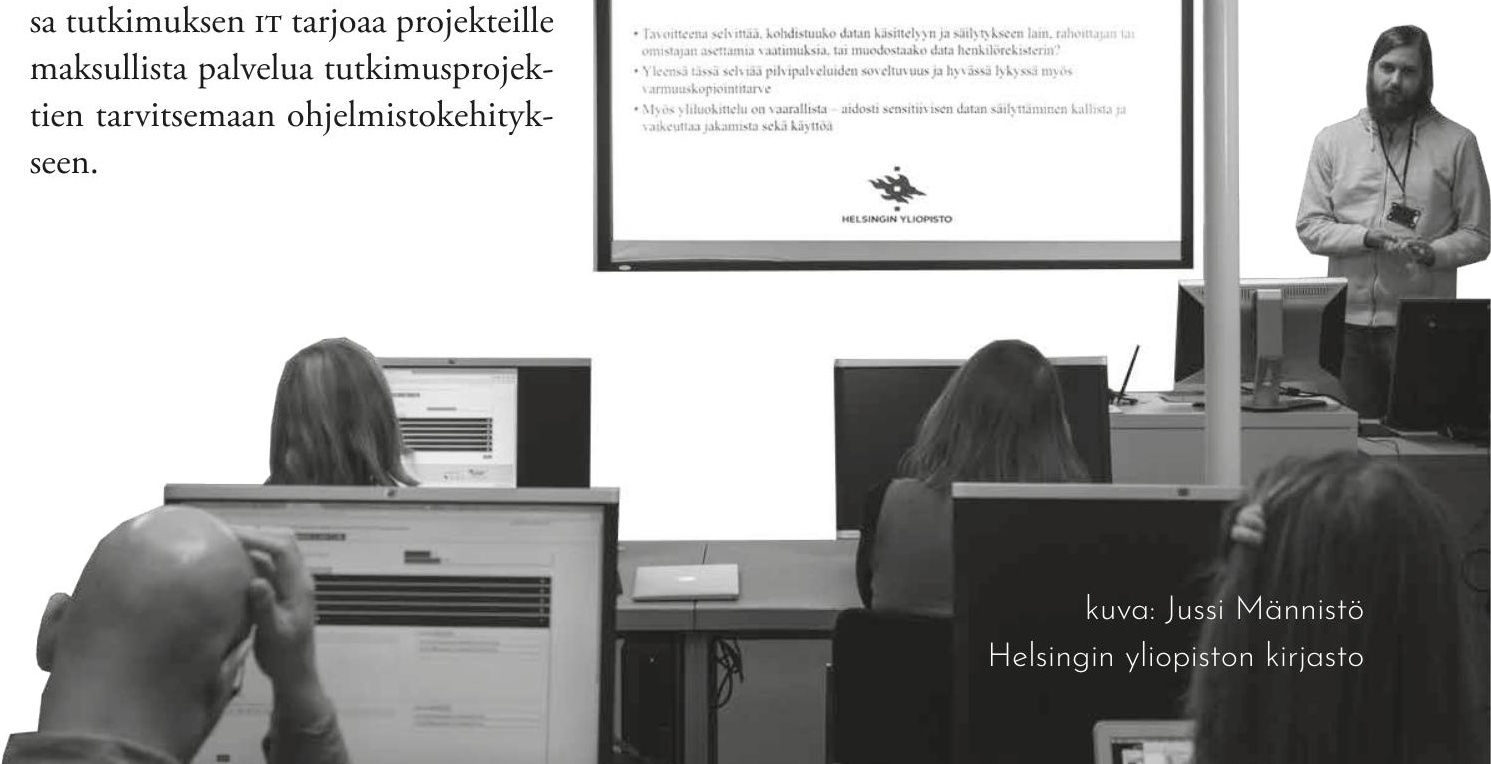


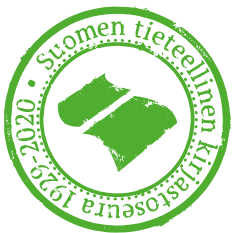

Tärkeä tavoite on myös saada datanhallintasuunnitelmat tehokkaammin mukaan palveluprosesseihin. Uutta liiketoimintamallia palvelujen järjestämiseksi pohditaan. Suunnitteilla on tutkimusprojekteille ja -infroille suunnattu maksullinen datavoutipalvelu (data steward), joka syventäisi nykyisiä palveluja ja mahdollistaisi datatuessa vakituisesti työskentelevän datavoudin osa-aikaisen osallistumisen tutkimusprojektin datanhallinnan kehittämiseen tai käytännön työhön. Vastaavanlainen palvelu on ollut käytössä Utrechtin yliopistossa. Näiden lisäksi kehitetään mm. uusia syventäviä koulutuskonsepteja, päätetään perustutkintovaiheen osaamistavoitteista, mietitään datan metriikkaa, ja pyritään saamaan tutkimusdatan pitkäaikaissäilytyksen tuki sekä siihen tarvittava kuratointipalvelu toimintaan.

SeAmкissa on parhaillaan erityisenä kehityskohteena palvelu, joka mahdollistaa hankkeissa kerättyjen aineistojen kuvailutietojen keräämisen. Kuvailutiedot lisätään SeAmkin oman projektinhallintajärjestelmän yhteydessä olevaan Aineistot-metatietokantaan (https://www.seamk.fi/aineistot), josta tiedot ovat kaikkien tarkasteltavissa. Tietojen tallentaminen on tärkeää myös siksi, että tiedetään, mitä aineistoja SeAmkin hankkeissa on ylipäätään kerätty.

Tampereen yliopistossa ajankohtaista on systemaattisen tuen jatkokehittäminen postdoc-vaiheen tutkijoille ja tieteenalakohtaisten ja tutkimusprojekteille tarjottavien palveluiden lisää- minen. Tammikuussa 202 I käynnistyy Dynaamiset DMP:t projekti. Päättyvät projektit (pAsdata ja Tutkimusaineistot organisaatioissa) tulevat näkymään toimenpiteissä erityisesti vuodesta 202 I eteenpäin. Pidemmän aikavälin tavoitteet lähivuosille ovat samankaltaiset kuin HY:llä, tarkoituksena on esimerkiksi benchmarkata Utrechtin ja Delftin yliopistojen toimintamalleja.

Turun yliopistossa käynnistetään vuoden 202 I alussa uutena palveluna Turun yliopiston datakatalogi, johon tutkijat voivat kirjata tutkimusprojektiensa aineistojen metatiedot ja saada dataseteille pysyvän DOI-tunnisteen, jonka avulla datakatalogiin tallennettu metadata, ulkoiseen repositorioon arkistoitu data, UTUCRIs-tutkimustietojärjestelmään tallennetut tutkimusjulkaisujen metatiedot ja UTUPub-julkaisuarkistoon tallennettavat julkaisujen rinnakkaistallenteet voidaan linkittää toisiinsa. Palvelua tuottavat yhteistyössä tutkimusedellytykset-yksikkö, tutkimuksen IT ja kirjasto.

\section{Yhteenveto}

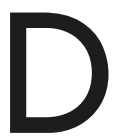
atakoulutukset ja -palvelut ovat oleellisia toimintoja avoimen tieteen edistämisessä. Kenttä on jatkuvassa liikkeessä, joten yhteistyö sekä kansallisella että kansainvälisellä tasolla on oleellista. Avoimen tieteen koordinaation työryhmät ja Tuulitoimisto tarjoavat foorumin sekä hyvien käytäntöjen jakamiselle että yhdessä tehtävälle kansalliselle kehitystyölle.

Datakoulutusten ja -palvelujen tar- 
jonnan historia on toistaiseksi vielä melko lyhyt. Kirjastoilla ja Aalto-yliopiston tapauksessa tutkimuspalveluihin sijoitetulla tiimillä on keskeinen koordinointi- ja koulutusvastuu, mutta työtä tehdään yleensä verkostomaisesti yhtä lailla organisaation yksikköjen välillä kuin myös kansallisesti ja kansainvälisesti. Yhteistyön tekeminen on oleellista paitsi hyvien käytäntöjen ja tietämyksen jakamisen näkökulmasta, myös vähäisten resurssien vuoksi.

Koulutus, neuvonta ja aineistonhallintasuunnitelmien kommentointi ovat palvelujen lyhyehköstä historiasta huolimatta muotoutuneet eräänlaisiksi peruspalveluiksi, joskin esimerkiksi koulutusten organisointitavoissa on eroja. Lähitulevaisuuden suunnitelmissa korostuu tällä hetkellä tuotettujen tutkimusaineistojen koordinointi ja niihin liittyvän metadatan hallinta.

Datapalveluihin liittyvää viestintää ei palvelujen alkutaipaleella voi liikaa korostaa. Tietoisuutta datanhallinnan kysymyksistä on nostettu viestinnän, kampanjoiden ja kartoitusten avulla. Esimerkiksi SeAmkissa tehtiin vuonna 2016 kartoitus, jonka tavoitteena oli selvittää, millaisia tutkimusaineistoja ja tuloksia SeAmkin TKI-hankkeissa syntyy, miten niitä hallitaan ja millaisia näkemyksiä projektipäälliköillä on aineistojen ja tulosten avaamisesta (Päällysaho \& Latvanen 2016).

Koulutusten ja palvelujen kehittämiseksi tarvitaan jatkuvaa seurantaa ja yhteistyötä eri asiakasryhmien kanssa. Turun yliopiston BRDM-kurssin survey-kyselyjen, kurssipalautteiden ja kurssilla tehtyjen aineistonhallintasuunnitelmien analyysin perusteella voidaan todeta, että datanhallinnan koulutuksella on merkitystä: vuonna 2020 kurssin kokonaan suorittaneet tohtorikoulutettavat arvioivat osaamisensa parantuneen keskimäärin 7I

On tärkeä muistaa, että mielenkiintoista ja tärkeää kehitystyötä tehdään tässä jutussa tarkasteltujen korkeakoulujen lisäksi kaiken aikaa myös muualla. Tulevaisuudessa olisi kiinnostavaa vertailla käytäntöjä kattavammin paitsi korkeakouluissa, myös esimerkiksi tutkimuslaitoksissa.

\section{Organisaatioiden} datanhallinnan verkkosivut

- Aalto-yliopisto: https://www.aalto.fi/rdm

- Helsingin yliopisto: https://www. helsinki.fi/fi/tutkimus/palveluttutkijoille-ja-tutkimuksen-linjauksia/ aineistonhallinta

- Seinäjoen ammattikorkeakoulu: https://seamk.libguides.com/ avoinTKI-toimintaSeAMKopas/ etusivu

- Tampereen yliopisto: https:// research.tuni.fi/datapalvelu/

- Turun yliopisto: https://utuguides.fi/ tutkimusdata

\section{Organisaatioiden} datanhallinnan palveluosoitteet

- Aalto-yliopisto: researchdata@aalto.fi

- Helsingin yliopisto: datasupport@helsinki.fi

- Seinäjoen ammattikorkeakoulu: avointkituki@seamk.fi

- Tampereen yliopisto: researchdata@tuni.fi

- Turun yliopisto: openutu@utu.fi,data@utu.fi 


\section{Lähteet}

Datakoulutukset-työryhmän lista datakoulutuksista https://bit.ly/2TOGEAn

Nykyri, S. \& NÄppilä, T. (2019, November). Research Data Services @ Tampere

University. Zenodo. http://doi.org/I0.528I/zenodo.3541709

PäÄllysaho, S. \& Latvanen, J. (20I6). Avoimuus tKi-hankkeiden aineistonhallinnassa :

Case Seamk https://www.theseus.fi/handle/ı $0024 /$ I 18838

Rantasaari, J. (2020). Perceptions of Doctoral Students' Current Research Data

Management Competencies and the Perceived Importance of these Competencies.

Manuscript submitted for publication.

RANTASAari, J. (2020). Implementing and assessing 3 ECTS the Basics of Research Data Management (BRDM) Course. Manuscript in preparation.

Rantasaari, J., \& KoKkinen, H. (2019). Closing the skills gap: the Basics of the Research Data Management (вRDM) Course: Case University of Turku. In: Proceedings of the 40th annual IATUL conference, 23-27 June 2019, Available at:

https://docs.lib.purdue.edu/iatul/2019/fair/5/ (accessed I I November 2020).

Unescon open science draft recommendations (https:/en.unesco.org/sites/default/files/ en-unesco_osr_first_draft.pdf

Violos, John, Christos, Kontzinos, Androutsopoulou, Marika, Askounis, Dimitrios, Kokkinakos, Panagiotis, Siegert, Olaf, ... Nykyri, Susanna. (2020, June). Liber 2020 - Session \#7: Super-Charging Your RDM Impact. Zenodo. http://doi.org/I0.528I/zenodo.3909428

\section{Kirjoittajat:}

\author{
Mari-Elisa KuUsniemi \\ Helsingin yliopisto \\ mari-elisa.kuusniemi@helsinki.fi
}

\author{
SusANNA NyKYri \\ Tampereen yliopisto \\ susanna.nykyri@tuni.fi
}

Seliina PäÄLlysaho

Seinäjoen ammattikorkeakoulu seliina.paallysaho@seamk.fi
JUKKa RANTASAARI

Turun yliopisto

jukka.rantasaari@utu.fi

\author{
Eeva Savolainen \\ Aalto-yliopisto \\ eeva.savolainen@aalto.fi
}

Anne Sunikka
Aalto-yliopisto
anne.sunikka@aalto.fi 